\title{
ХАРАКТЕРИСТИКА ДІЯЛЬНОСТІ АМБУЛАТОРНИХ ЗАКЛАДІВ МІСТА КИЄВА ЗА УМОВ РЕФОРМУВАННЯ СИСТЕМИ ОХОРОНИ ЗДОРОВ'Я
}

\author{
Національна медична академія післядипломної освіти імені П.Л. Шупика, м. Київ, Україна
}

\begin{abstract}
Створення нових структур у системі охорони здоров'я вимагає комплексного і ретельного аналізу їх діяльності 3 метою обґрунтування можливостей удосконалення ії організації.

Мета: проаналізувати ресурси і діяльність мережі амбулаторно-поліклінічних закладів, консультативнодіагностичних центрів у м. Києві в 2014-2016 рр.

Матеріали і методи. Матеріалами для проведення аналізу були дані звітних статистичних фрорм № 17, № 20, а також статистичні довідники Київського міського інформаційно-аналітичного центру.

Результати. У м. Києві на базі існуючих поліклінік створено 28 центрів первинної медико-санітарної допомоги та 13 консультативно-діагностичних центрів. Консультативно-діагностичні центри забезпечують 38,6-57,1 \% серед усіх відвідувань амбулаторно-поліклінічних закладів. Основними ресурсними проблемами консультативнодіагностичних центрів $€$ недостатнє орінансування, застаріле лікувально-діагностичне обладнання, неповна укомплектованість кадрів.

Висновки. Виявлені характерні особливості діяльності консультативно-діагностичних центрів будуть враховані при розробці функціонально-організаційної моделі консультативно-діагностичних центрів на принципах ДПП.
\end{abstract}

КЛЮчОВІ СЛОВА: амбулаторно-поліклінічні заклади у м. Києві; ресурси; показники діяльності.

Провідна роль у збереженні та зміцненні стану здоров'я населення належить амбулаторно-поліклінічній допомозі і насамперед її первинній ланці [1].

Актуальною проблемою вітчизняної системи охорони здоров'я $€$ необхідність переходу ії на прогресивні моделі розвитку, які забезпечують структурну ефективність галузі [2, 3]. Важливим інструментом вирішення даного завдання $€$ удосконалення системи амбулаторної допомоги, у якій повинні розпочинати і завершувати своє лікування до 90 \% пацієнтів, які звернулися за медичною допомогою [4].

Удосконалення амбулаторно-поліклінічної допомоги є ключовим напрямком модернізації вітчизняної системи охорони здоров'я. Загальний рівень доступності та якості медичної допомоги значною мірою визначається на даному їі етапі. В Україні впродовж останніх років на законодавчому рівні неодноразово декларувались завдання пріоритетного розвитку амбулаторно-поліклінічної допомоги та здійснення реформ в організації первинної медичної допомоги $[4,5]$.

У м. Києві, відповідно до Закону України від 07.07.2011 р. № 3612 «Про порядок проведення реформування системи охорони здоров'я у Вінницькій, Дніпропетровській, Донецькій областях та місті Києві» [5], здійснено реформування системи охорони здоров'я, яке призвело до розмежування первинної та вторинної медичної допомоги, у т. ч. тієї, що надається в амбулаторних

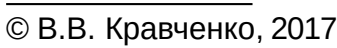

умовах. У м. Києві амбулаторно-поліклінічні заклади (АПЗ) із обслуговування дорослого та дитячого населення реорганізовані у Центри первинної медико-санітарної допомоги (ЦПМСД) та консультативно-діагностичні центри (КДЦ), які надають первинну та вторинну амбулаторну допомогу без вікового розподілу населення.

Запровадження нових організаційних фрорм надання медичної допомоги та створення нових структур у системі охорони здоров'я потребує комплексного та ретельного аналізу їх діяльності 3 метою оцінки досвіду та доцільності його подальшого використання.

Мета роботи: проаналізувати ресурси і діяльність мережі АПЗ, консультативно-діагностичних центрів у м. Києві в 2014-2016 рр.

Матеріали і методи. Матеріалами для проведення аналізу були дані звітних статистичних форм № 20 «Звіт лікувально-профрілактичного закладу» та № 17 «Звіт про медичні кадри» окремих закладів та зведених по районах та по м. Києву, а також статистичні довідники Київського міського інфрормаційно-аналітичного центру [6].

Результати дослідження та їх обговорення. У м. Києві, відповідно до Закону України від 07.07.2011 р. № 3612 [5], у 2011 р. стартувала реформа системи охорони здоров'я.

На першому етапі (у 2011-2012 рр.) здійснено ресрормування у двох пілотних - Дарницькому та Дніпровському районах, на другому етапі (у 2013 та на початку 2014 р.) - в інших 8-ми районах міста. 
Аналіз мережі амбулаторно-поліклінічних закладів у м. Києві показав, що у м. Києві в ході реалізації пілотного проекту реорормування системи охорони здоров'я на базі існуючих поліклінік створено 28 центрів первинної медико-санітарної допомоги, до складу яких входять 82 відокремлені амбулаторії, та 13 консультативно-діагностичних центрів, 3 них 2 - дитячі. Зі створенням центрів первинної медико-санітарної допомоги загальна кількість амбулаторій загальної практики - сімейної медицини на кінець 2016 р. становила 257. Усі заклади функціонують як комунальні некомерційні підприємства.

Аналіз кадрових ресурсів первинної ланки системи охорони здоров'я у м. Києві виявив, що для надання первинної медико-санітарної допомоги населенню передбачено 2 201,5 штатних посад лікарів, із них 1 128,75 посад лікарів загальної практики - сімейної медицини, 642,75 посад дільничних педіатрів, 430 - дільничних терапевтів.

Усього на зазначених посадах працювали 1613 лікарів, у тому числі 837 лікарів сімейної медицини, 484 дільничних педіатри та 292 дільничних терапевтів. У цілому укомплектованість посад лікарів первинної медико-санітарної допомоги складала 73,3 \%. Посади лікарів загальної практики укомплектовані на 74,2 \%, дільничних педіатрів на 75,3 \%, дільничних терапевтів - на 67,9\%.

Проведений аналіз деяких показників діяльності АПЗ засвідчив, що у 2016 р. до лікарів амбулаторних закладів м. Києва було зроблено 28 951,3 тис. відвідувань, що у середньому на одного жителя складало 10,0 відвідувань (проти 10,1 у 2015 р.) (табл. 1).
Середня кількість відвідувань у розрахунку на одного жителя у районах м. Києва характеризувалась середнім ступенем варіації (коефріцієнт варіації (КВ) становив 20,9 \%) та від мінімального значення у Солом'янському $(5,0)$ до максимального у Дніпровському районі $(11,4)$.

Про відносну стабільність територіального розподілу даного показника у динаміці свідчить наявність прямого сильного кореляційного зв'язку між його територіальними значеннями у 2015 та 2016 pp. (r=0,99, p<0,05). Щороку перевищували верхній квартиль територіального розподілу показники у Дніпровському, Шевченківському та Дарницькому районах і знаходились нижче першого квартиля у Солом'янському районі.

Одним із пріоритетних напрямків у роботі закладів, які надають амбулаторну допомогу, є розвиток стаціонарозамінних видів медичної допомоги населенню. Для здійснення раціонального використання обмежених коштів у м. Києві розширюється мережа денних стаціонарів та стаціонарів вдома для надання кваліфрікованої медичної допомоги хворим, які не потребують цілодобового нагляду.

Функціонує мережа денних стаціонарів при амбулаторних закладах та стаціонарів вдома. Кількість ліжок у таких стаціонарах загалом по місту на кінець 2016 р. складала 1 745, чисельність пролікованих хворих - 143,2 тис. (132,9 тис. у 2015 р.). У стаціонарах вдома було проліковано 279,6 тис. хворих (у 2015 р. - 277,7 тис.).

У закладах охорони здоров'я, підпорядкованих УОЗ РДА, нараховується 1161 ліжко денного стаціонару для дорослих (табл. 2), на яких було проліковано понад 121,3 тис. хворих (111,4 тис. у 2015 р.).

Таблиця 1. Кількість відвідувань до лікарів у районах м. Києва (2015-2016 рр.)

\begin{tabular}{|l|c|c|c|c|}
\hline \multirow{2}{*}{ Райони м. Києва } & \multicolumn{2}{c|}{ Абсолютна кількість відвідувань } & \multicolumn{2}{c|}{ Кількість відвідувань на одного жителя } \\
\cline { 2 - 5 } & 2015 & 2016 & 2015 & 2016 \\
\hline Голосіївський & 2024345 & 2105444 & 8,1 & 8,4 \\
\hline Дарницький & 2911021 & 2896467 & 8,8 & 8,7 \\
\hline Деснянський & 3050306 & 2997285 & 8,3 & 11,4 \\
\hline Дніпровський & 4112360 & 4026622 & 11,6 & 7,3 \\
\hline Оболонський & 2326842 & 2348655 & 7,3 & 7,7 \\
\hline Печерський & 844318 & 837668 & 6,9 & 8,2 \\
\hline Подільський & 1395033 & 1399211 & 7,2 & 5,0 \\
\hline Святошинський & 2741734 & 2693954 & 8,4 & 9,1 \\
\hline Солом'янський & 1866527 & 1862416 & 5,1 & 8,1 \\
\hline Шевченківський & 2404272 & 2387699 & 9,1 & 10,0 \\
\hline Всього по районах & 23676758 & 23555421 & 8,2 & 8,0 \\
\hline Всього у м. Києві & & 10,1 & 1,7 \\
\hline Середня арифметична & & & 8,1 & 20,9 \\
\hline Середн. квадр. відхилення & & & 1,7 & 5,0 \\
\hline Коефріцієнт варіації & & & 20,9 & 11,4 \\
\hline Мінімум & & 5,1 & 11,6 & 7,2 \\
\hline Максимум & & 7,2 & \\
\hline Нижній квартиль & & & 8,7 & \\
\hline Верхній квартиль & & & \\
\hline
\end{tabular}


Таблиця 2. Мережа та показники діяльності денних стаціонарів для надання медичної допомоги дорослому населенню у районах м. Києва (2015-2016 рр.)

\begin{tabular}{|l|c|c|c|c|c|c|c|c|}
\hline \multirow{2}{*}{ Райони } & \multicolumn{2}{|c|}{ Кількість ліжок } & \multicolumn{2}{c|}{$\begin{array}{c}\text { На 10 тис. } \\
\text { населення }\end{array}$} & \multicolumn{2}{c|}{ Проліковано хворих } & \multicolumn{2}{c|}{$\begin{array}{c}\text { Середня тривалість } \\
\text { лікування хворого }\end{array}$} \\
\cline { 2 - 11 } & 2015 & 2016 & 2015 & 2016 & 2015 & 2016 & 2015 & 2016 \\
\hline Голосіївський & 85 & 88 & 4,2 & 4,4 & 6692 & 7324 & 6,3 & 6,3 \\
\hline Дарницький & 157 & 157 & 6,3 & 6,3 & 15563 & 15672 & 9,1 & 9,1 \\
\hline Деснянський & 140 & 140 & 4,9 & 4,9 & 13700 & 13925 & 7,2 & 7,6 \\
\hline Дніпровський & 173 & 173 & 6,1 & 6,1 & 14130 & 13765 & 8,1 & 8,2 \\
\hline Оболонський & 103 & 103 & 3,9 & 3,9 & 11657 & 19969 & 9,6 & 8,6 \\
\hline Печерський & 65 & 65 & 6,1 & 6,0 & 4817 & 5033 & 7,9 & 7,1 \\
\hline Подільський & 126 & 126 & 8,3 & 8,2 & 5625 & 5398 & 7,5 & 7,5 \\
\hline Святошинський & 98 & 98 & 3,8 & 3,8 & 12127 & 11770 & 9,0 & 8,9 \\
\hline Солом'янський & 82 & 82 & 2,6 & 2,6 & 18745 & 18273 & 4,2 & 3,9 \\
\hline Шевченківський & 139 & 129 & 6,6 & 6,2 & 8389 & 10185 & 8,4 & 7,7 \\
\hline Всього & 1168 & 1161 & 5,0 & 5,0 & 111445 & 121314 & 7,6 & 7,5 \\
\hline
\end{tabular}

Найвища забезпеченість ліжками денних стаціонарів у Подільському (8,2 на 10 тис. населення) та в Дарницькому (6,3 на 10 тис. населення) районах. Середня тривалість лікування у денних стаціонарах складала 7,5 днів, а її значення коливались від 3,9 днів у Солом'янському до 9,1 днів у Дарницькому районах.

Профріль ліжкового фронду денних стаціонарів визначався нозологічною структурою поширеності хвороб. У структурі ліжок денних стаціонарів дорослого населення найбільшу частку складають загальнотерапевтичні (41,0 \%) та неврологічні (15,3 \%). Потребує подальшого розвитку мережа кардіологічних ліжок денних стаціонарів (станом на 2016 р. розгорнуто 101 ліжко), що дозволить підвищити ефрективність вторинної профрілактики хвороб системи кровообігу та покращити якість життя пацієнтів.

Варто відзначити, що резерв для збільшення кількості ліжок денного стаціонару практично вичерпаний, що насамперед пов'язано з відсутністю вільних площ в амбулаторних закладах, більшість яких побудована у 70-х роках минулого сторіччя та $€$ недостатньою в районі новобудов.

Аналіз ресурсного забезпечення та діяльності консультативно-діагностичних центрів у м. Києві засвідчив, що амбулаторну вторинну медичну допомогу (ВМД) жителям м. Києва надають 13 консультативно-діагностичних центрів, у т. ч. 2 для обслуговування дитячого населення, тобто доросле населення столиці обслуговується 11 КДЦ. Примірне положення про КДЦ затверджене наказом МОЗ України від 30.12.2011 р. № 1008 [7].

Основними завданнями КДЦ є:

1. Надання консультативно-діагностичної медичної допомоги пацієнтам, які звернулися за направленням до лікарів загальної практики - сімейних лікарів району м. Києва, лікарів інших закладів охорони здоров'я.
2. Проведення необхідних консультацій та обстежень для підтвердження діагнозу, визначення тяжкості стану пацієнта та місця подальшого його дообстеження, консультування, лікування та реабілітації, за необхідності направлення пацієнта на госпіталізацію до стаціонарних відділень закладів охорони здоров'я.

3. Організація взаємодії із закладами охорони здоров'я, які надають первинну, вторинну, третинну, екстрену медичну допомогу та здійснюють медичну реабілітацію.

4. Організація та надання невідкладної медичної допомоги населенню в амбулаторних умовах.

5. Планування розвитку КДЦ.

6. Медична практика.

7. Проведення організаційно-методичної роботи за напрямком амбулаторної ВМД.

8. Здійснення фінансового, матеріально-технічного забезпечення амбулаторної ВМД та кадрового укомплектування.

9. Забезпечення взаємодії між структурними і відокремленими структурними підрозділами КДЦ в інтересах збереження та зміцнення здоров'я населення та удосконалення надання медичної допомоги.

Утримання КДЦ і оплату праці здійснюють за рахунок коштів бюджету м. Києва, а також коштів, отримання яких передбачене законодавством України.

Матеріально-технічну базу і кошти КДЦ складають основні фонди та оборотні кошти, а також інші матеріальні цінності та фрінансові ресурси, вартість яких відображена у його самостійному балансі.

Майно КДЦ належить до комунальної власності територіальної громади м. Києва і закріплене за ним на праві оперативного управління.

Для аналізу ресурсного забезпечення та діяльності КДЦ у м. Києві шляхом типологічного добору було відібрано 3 з 11 КДЦ, які обслуговують доросле населення: назвемо їх КДЦ А, Б та В районів. 
Дані заклади мають типову для КДЦ у м. Києві потужність, структуру та матеріально-технічне оснащення.

КДЦ району А у 2016 р. обслуговував 239735 дорослого населення, Б - 202 304, В - 152854. Планова потужність КДЦ району А становила 970, Б - 1 253, В - 1000 відвідувань за зміну. Фактична, відповідно, 2 549, 3 291, 2612 відвідувань за зміну. Таким чином, фрактична потужність у всіх трьох КДЦ у 2,6 раза перевищувала планову.

Аналіз матеріально-технічного стану КДЦ засвідчив, що впродовж 2014-2016 рр. фрінансування загального фонду бюджету КДЦ складало 50-80 \% від потреби. Нагальною потребою усіх КДЦ є заміна і оновлення існуючого морально застарілого та фрізично зношеного обладнання 3 $100 \%$ вичерпаним експлуатаційним ресурсом. Потреба у високовартісному обладнанні у кожному КДЦ становить 9-13 млн грн.

Лікарський прийом у КДЦ здійснюється більш ніж за 20-ма спеціальностями. У всіх трьох закладах медичну допомогу дорослому населенню забезпечують лікарі таких спеціальностей: терапевти, пульмонологи, ревматологи, кардіологи, гастроентерологи, ендокринологи, інфекціоністи, фрізіотерапевти, лікарі 3 функціональної діагностики, хірурги, ортопеди-травматологи, урологи, ендоскопісти, онкологи, стоматологи, акушеригінекологи, офтальмологи, отоларингологи, невропатологи, дерматовенерологи, бактеріологи, лікарі-лаборанти, лікарі з ультразвукової діагностики, рентгенологи. Крім того, у КДЦ А та Б районів ведуть прийом нефролог, алерголог, лікарі з лікувальної фрізкультури, лікарі-психологи.

Аналіз кадрових ресурсів КДЦ району А засвідчив, що у закладі передбачено 291,75 штатних посад лікарів та 405,0 штатних посад середнього медичного персоналу, які укомплектовані на 86,3 та 83,1 \%, відповідно.

Серед лікарських посад найнижчі показники укомплектованості посад лікарів-онкологів (53,8 \%), лікарів фрункціональної діагностики (54,2 \%), лікарів-інфекціоністів (66,7 \%) та лікарівендоскопістів $(75,0 \%)$.

81,6 \% лікарів мають кваліфікаційні категорії. Більше половини (56,3 \%) 3 атестованих лікарів має вищу категорію, майже третина (29,3 \%) першу і кожний сьомий (14,4 \%) - другу.

Штатним розписом КДЦ району Б передбачено 357,25 лікарських посад і 498,25 посад середнього медичного персоналу, які укомплектовані лише на 78,9 та 72,5 \%, відповідно. У даному закладі укомплектованість медичних кадрів $€$ найнижчою серед досліджуваних КДЦ.

У розрізі окремих лікарських спеціальностей найгірше у КДЦ району Б укомплектовані посади рентгенологів (48,4\%), інфекціоністів (56,5\%), офртальмологів (57,9 \%), лікарів із фрункціональної діагностики (58,6 \%), лікарів-лаборантів (64,7 \%). У кДЦ району Б найменшою $є$ і частка атестованих лікарів (73,1 \%). Серед атестованих лікарів 49,5 \% мають вищу категорію, 36,8 \% - першу і 13,7 \% - другу.

У КДЦ району В передбачено 178,75 штатних посад лікарів та 241,25 посад середнього медичного персоналу. Даний заклад має найвищу серед порівнюваних КДЦ укомплектованість медичних кадрів: 93,7 \% за посадами лікарів та 83,3 \% за посадами середнього медичного персоналу.

Найнижчими у закладі є показники укомплектованості посад лікарів-онкологів (75,0 \%), отоларингологів (76,5 \%), офртальмологів (88,2 \%).

Серед усіх лікарів КДЦ району В 78,9 \% має кваліфікаційну категорію. Серед атестованих лікарів 64,1 \% вищу категорію, 24,1 \% - першу і 14,5 \% другу.

Таким чином, для кадрових ресурсів у всіх досліджуваних КДЦ характерні такі особливості: неповна укомплектованість медичних кадрів (посади лікарів укомплектовані на 78,9-93,7 \%, середнього медичного персоналу - на 72,5-83,3 \%); коефіцієнт сумісництва лікарів знаходиться на рівні 0,9-1,0; співвідношення посад середнього медичного персоналу до лікарських посад складає 1,4 до 1,0; частка атестованих лікарів становить 73,181,6 \%; серед атестованих лікарів 50-64,1 \% мають вищу квалісрікаційну категорію, 21,1-36,8 \% першу, 13,7-14,5 \% - другу.

Аналіз діяльності КДЦ району А щодо надання амбулаторної ВМД показав, що даний заклад щороку обслуговує понад 1 млн відвідувань, більшість яких $€$ з приводу захворювань (67-70\%). Частка профілактичних відвідувань складає третину серед усіх відвідувань та коливається у межах 28-32 \%, а питома вага відвідувань лікарями хворих вдома не перевищує 2,0 \% (табл. 3).

Аналіз динаміки кількості відвідувань засвідчив скорочення абсолютної кількості відвідувань до даного закладу на 14,5 \%, а у розрахунку на одного жителя на 13,7 \% (3 5,1 до 4,4).

КДЦ району Б щороку обслуговує майже 1 млн відвідувань і за три роки значення даного показника зросло на 6,3 \%. На 5,0 \% підвищився і показник середньої кількості відвідувань у розрахунку на одного жителя (з 4,6 до 4,8). Структура відвідувань аналогічна до КДЦ району А.

КДЦ району В характеризується не тільки найменшою серед досліджуваних закладів абсолютною кількістю відвідувань (що є зрозумілим, адже даний заклад має найменшу кількість прикріпленого населення), але й найнижчим значенням середньої кількості відвідувань у розрахунку на одного жителя. Динамічний аналіз виявив тенденцію до зниження як абсолютної кількості відвідувань (на 8,3 \%), так і показника у розрахунку на одного жителя (на 9,7 \% з 3,6 до 3,3). Особливістю 
Таблиця 3. Характеристика відвідувань до трьох КДЦ м. Києва (2014-2016 рр.)

\begin{tabular}{|c|c|c|c|c|}
\hline Показник & 2014 & 2015 & 2016 & $\begin{array}{c}\text { Темп приросту } \\
\text { (\%) }\end{array}$ \\
\hline \multicolumn{5}{|c|}{ КДЦ району А } \\
\hline Кількість відвідувань всього (абс.) & 1220680 & 1161517 & 1043229 & $-14,5$ \\
\hline Кількість відвідувань на одного жителя & 5,1 & 4,8 & 4,4 & $-13,7$ \\
\hline Питома вага профрілактичних відвідувань (\%) & 30,4 & 31,4 & 28,3 & \\
\hline $\begin{array}{l}\text { Питома вага профілактичних відвідувань } 3 \text { приводу } \\
\text { захворювань (\%) }\end{array}$ & 67,9 & 67,0 & 69,9 & \\
\hline Питома вага відвідувань лікарями хворих вдома (\%) & 1,7 & 1,6 & 1,8 & \\
\hline \multicolumn{5}{|c|}{ КДЦ району Б } \\
\hline Кількість відвідувань всього (абс.) & 921469 & 917519 & 979795 & 6,3 \\
\hline Кількість відвідувань на одного жителя & 4,6 & 4,6 & 4,8 & 5,0 \\
\hline Питома вага профрілактичних відвідувань (\%) & 32,2 & 30,5 & 31,7 & \\
\hline $\begin{array}{l}\text { Питома вага профілактичних відвідувань } 3 \text { приводу } \\
\text { захворювань (\%) }\end{array}$ & 66,7 & 68,3 & 67,4 & \\
\hline Питома вага відвідувань лікарями хворих вдома (\%) & 1,2 & 1,2 & 1,0 & \\
\hline \multicolumn{5}{|c|}{ КДЦ району В } \\
\hline Кількість відвідувань всього (абс.) & 545499 & 505403 & 500145 & $-8,3$ \\
\hline Кількість відвідувань на одного жителя & 3,6 & 3,3 & 3,3 & $-9,7$ \\
\hline Питома вага профрілактичних відвідувань (\%) & 24,8 & 26,3 & 25,6 & \\
\hline $\begin{array}{l}\text { Питома вага профрілактичних відвідувань з приводу } \\
\text { захворювань (\%) }\end{array}$ & 72,6 & 72,0 & 73,0 & \\
\hline Питома вага відвідувань лікарями хворих вдома (\%) & 2,6 & 1,7 & 1,5 & \\
\hline
\end{tabular}

структури відвідувань до даного закладу є те, що профрілактичні відвідування складають не третину, як у КДЦ районів А та Б, а чверть від усіх відвідувань (25,6 \% у 2016 р.)

Таким чином, КДЦ забезпечують 38,6-57,1 \% серед усіх відвідувань до АПЗ, що свідчить про вагомий внесок даних закладів у наданні амбулаторно-поліклінічної допомоги дорослому населенню столиці, а також структурні диспропорції у діяльності первинної та вторинної ланки системи охорони здоров'я. 34,6 \% пацієнтів звертаються до КДЦ без направлення лікаря загальної практики сімейної медицини.

Аналіз структури відвідувань до лікарів у розрізі лікарських спеціальностей (табл. 4.) засвідчив, що чверть серед усіх відвідувань до КДЦ складають відвідування до акушерів-гінекологів (24,7-27,2\%), приблизно кожне десяте відвідування до лікарів-хірургів (9,1-13,0 \%). Наступні позиції у структурі відвідувань до КДЦ - відвідування до невропатологів (5,9-10,1 \% серед усіх відвідувань), отоларингологів (6,8-10,2 \%), ортопедів-травматологів (6,0-10,0\%), офтальмологів (5,1-8,4 \%), ендокринологів (2,9-4,7\%). У цілому відвідування до лікарів перерахованих 7-ми спеціальностей складають 68-75 \% серед усіх відвідувань до КДЦ.

Аналіз профрілактичного напрямку діяльності КДЦ дозволив встановити, що профілактичні від- відування становлять від чверті до третини серед усіх відвідувань до лікарів (28,3 \% у районі А, 31,5 \% у районі Б, 25,6 \% у районі В, дані за 2016 р.).

Показник виконання плану профоглядів $€$ високим у всіх закладах, так у 2016 р. він складав 97,8 \% у КДЦ районуА, 99,2 \% - у Б, $100 \%$ - у В.

У той же час за значенням показника виконання плану флюорографічних оглядів КДЦ дуже відрізняються: $100 \%$ у районі B, 96,0 \% у районі А та лише 45,5 \% у районі Б. Низький показник у даному районі зумовлений виходом із ладу флюорографрічного обладнання.

Питома вага жінок, які пройшли огляд 3 цитологічним обстеженням, серед тих, які йому підлягали, складала 99,7 \% у КДЦ району Б, 84,1 \% - у КДЦ району А, а у КДЦ району В - тільки 50,2 \%.

Більше половини злоякісних новоутворень, які діагностуються у КДЦ, виявляються на профоглядах. У 2016 р. питома вага злоякісних новоутворень, виявлених на профоглядах, становила 66, 7\% у районі А, 56,4 \% - у Б та 50,1\% - у В.

Питома вага злоякісних новоутворень, виявлених у занедбаних стадіях, є показником, який використовується для оцінки результативності профрілактичної роботи, спрямованої на своєчасне виявлення злоякісних новоутворень. Значення даного показника коливалось у досліджуваних районах від 7,5 до 4,1 \% (при середньому по м. Києву в 2016 р. 9,4\%). 
Таблиця 4. Структура відвідувань до лікарів у розрізі окремих спеціальностей, три Кдц м. Києва (2016 р.)

\begin{tabular}{|l|c|c|c|}
\hline \multicolumn{1}{|c|}{ Посади лікарів } & КДЦ району А & КДЦ району Б & КДЦ району В \\
\hline Акушери-гінекологи & 26,0 & 24,7 & 27,2 \\
\hline Хірурги & 13,0 & 10,1 & 9,1 \\
\hline Невропатологи & 9,1 & 5,9 & 10,1 \\
\hline Отоларингологи & 6,8 & 10,2 & 1,9 \\
\hline Травматологи & 6,0 & 6,1 & 5,6 \\
\hline Ортальмологи & 5,1 & 8,4 & 4,5 \\
\hline Ендокринологи & 4,7 & 2,9 & 25,1 \\
\hline Інші & 29,3 & 31,7 & 100 \\
\hline Всього & 100 & 100 & \\
\hline
\end{tabular}

Спостерігається досить високим показник занедбаності візуальних фрорм злоякісних новоутворень. У м. Києві в 2016 р., кожний сьомий $(14,7 \%)$ хворий із вперше в житті діагностованою візуальною фрормою ЗН (ротової порожнини (С01-C10), молочної залози (C50) та шийки матки (C53)) мав занедбану стадію захворювання (III-IV). Серед досліджуваних районів показник коливався від 9,8 до 25,3\%.

Аналіз кореляційних матриць, які характеризували взаємозв'язок між показниками активності, своєчасності виявлення злоякісних новоутворень та дорічною летальністю у районах м. Києва, засвідчив наявність сильного зворотного зв'язку $(r=-0,93 ; p<0,05)$ між часткою злоякісних новоутворень, виявлених під час медичних оглядів, та дорічною летальністю та зворотного зв'язку середньої сили $(r=-0,64 ; p<0,05)$ між часткою злоякісних новоутворень, виявлених під час медичних оглядів, та показником занедбаності. Між занедбаністю та дорічною летальністю встановлено прямий зв'язок середньої сили $(r=0,59 ; p<0,05)$. Таким чином, медичні огляди є дієвою медико-організаційною технологією для своєчасного виявлення та подальшого ефективного лікування хворих із злоякісними новоутвореннями.

Основними напрямками підвищення своєчасності виявлення онкологічних захворювань серед жителів столиці має бути впровадження цільової диспансеризації населення, програм скринінгу ЗН, підвищення онкологічної настороженості у лікарів первинної ланки охорони здоров'я, доступності та якості діагностичних послуг, покращення оснащення консультативно-діагностичних центрів сучасним діагностичним устаткуванням.

\section{Висновки}

У м. Києві, відповідно до Закону України «Про порядок проведення реформування системи охорони здоров'я у Вінницькій, Дніпропетровській, Донецькій областях та місті Києві», здійснено реформування системи охорони здоров'я, у результаті якого на базі існуючих поліклінік створено 28 центрів первинної медико-санітарної допомоги та 13 консультативно-діагностичних центрів.
Усі 13 КДЦ є комунальними неприбутковими підприємствами, юридичними особами, які мають відокремлене майно, та відповідно до їх статутів здійснюють господарську некомерційну діяльність, спрямовану на досягнення, збереження та зміцнення здоров'я населення та інших соціальних результатів без мети одержання прибутку.

Аналіз фрінансового забезпечення та матеріально-технічного стану КДЦ засвідчив, що впродовж 2014-2016 рр. фрінансування загального фронду бюджету КДЦ складало 50-80 \% від потреби. Нагальною потребою усіх КДЦ є заміна і оновлення існуючого морально застарілого та фрізично зношеного обладнання 3100 \% вичерпаним експлуатаційним ресурсом. Потреба у високо вартісному обладнанні у кожному КДЦ становить на суму 9-13 млн грн.

Встановлено, що для кадрових ресурсів КДЦ характерні наступні особливості: неповна укомплектованість медичних кадрів (посади лікарів укомплектовані на 78,9-93,7 \%, середнього медичного персоналу - на 72,5-83,3 \%); частка атестованих лікарів становить 73,1-81,6 \%; серед атестованих лікарів 50-64,1 \% мають вищу кваліфрікаційну категорію, 21,1-36,8 \% - першу, 13,714,5 \% - другу.

КДЦ забезпечують 38,6-57,1 \% серед усіх відвідувань до АПЗ, що свідчить про вагомий внесок даних закладів у наданні амбулаторно-поліклінічної допомоги дорослому населенню столиці, а також структурні диспропорції у діяльності первинної та вторинної ланки системи охорони здоров'я. 34,6 \% пацієнтів звертаються до КДЦ без направлення лікаря загальної практики - сімейної медицини.

Аналіз структури відвідувань до лікарів у розрізі окремих лікарських спеціальностей засвідчив, що чверть серед усіх відвідувань до КДЦ складають відвідування до акушерів-гінекологів (24,7-27,2 \%), кожне десяте відвідування - до лікарів-хірургів (9,1-13,0 \%). Наступні позиції у структурі відвідувань до КДЦ - відвідування до невропатологів (5,9-10,1 \% серед усіх відвідувань), отоларингологів (6,8-10,2 \%), ортопедів-травматологів (6,0-10,0 \%), оортальмологів 
(5,1-8,4 \%), ендокринологів (2,9-4,7 \%). У цілому відвідування до лікарів перерахованих 7-ми спеціальностей складають 68-75 \% серед усіх відвідувань до КДЦ.

Профрілактичні відвідування становлять 25,631,5 \% від усіх відвідувань до КДЦ. У той же час залишаються надзвичайно низькими показники результативності активного виявлення онкологічних захворювань: у м. Києві кожний сьомий $(14,7 \%)$, а у окремих районах кожний п'ятий $(25,3$ \%) випадок злоякісного новоутворення візуальної локалізації виявляється у занедбаній стадії. Основними напрямками підвищення своєчасності виявлення онкологічних захворювань серед жителів столиці має бути впровадження цільової диспансеризації населення, програм скринінгу $3 \mathrm{H}$, підвищення онкологічної настороженості у лікарів первинної ланки охорони здоров'я, доступності та якості діагностичних послуг, покращення оснащення консультативно-діагностичних центрів сучасним діагностичним устаткуванням.

Перспективи подальших досліджень. Результати дослідження будуть використані при обґрунтуванні концептуальних напрямків удосконалення вторинної амбулаторної допомоги населенню м. Києва та розробці оптимізованої моделі КДЦ.

\section{Список літератури}

1. The World Health Report 2008: Primary Health Care, Now More Than Ever. - WHO, 2008. - 563 p.

2. Лехан В. М. Стратегія розвитку системи охорони здоров'я: український вимір / В. М. Лехан, Г. О. Слабкий, М. В. Шевченко // Україна. Здоров'я нації. - 2010. - № 1. - С. 5-23.

3. Орлова Н. М. Регіональна система охорони здоров'я: концептуальні підходи до фрормування її сучасної політики / Н. М. Орлова. - К., 2010. - 184 с.

4. Дорофеев В. М. Организация амбулаторно-поликлинической помощи городскому населению / В. М. Дорофеев. Гомель, 2008. - 64 с.

5. Про затвердження загальнодержавної програми розвитку первинної медико-санітарної допомоги на засадах сімейної на період до 2011 року : Закон України від 22.01.2010 р. № 1841- VI // Відомості Верховної Ради України. 2010. - № 13. - С. 380, стаття 126.

6. Про порядок проведення реформування системи охорони здоров'я у Вінницькій, Дніпропетровській, Донецькій областях та м. Києві : Закон України від 07.07.2011 р. № 3612-VI // Відомості Верховної Ради України. - 2012. № 12-13. - С. 81.

7. Основні показники здоров'я та медичної допомоги населенню м. Києва у 2015-2016 рр. - ГУОЗ м. Києва, МНІАЦМС, 2017. - 178 с.

8. Про затвердження примірних положень про заклади охорони здоров'я : наказ Міністерства охорони здоров'я України від 30.12.2011 р. № 1008. - Режим доступу : http://search.ligazakon.ua/l_doc2.nsf/link1/MOZ15003.html.

\section{References}

1. (2008). The World Health Report 2008: Primary Health Care, Now More Than Ever. WHO.

2. Lekhan, V.M., Slabkyi, H.O., \& Shevchenko, M.V. Stratehiia rozvytku systemy okhorony zdorovia: ukrainskyi vymir Ukraina [Health Care Development Strategy: Ukrainian Dimension]. Zdorovia natsii-Health of Nation, 1, 5-23 [in Ukrainian]. 3. Orlova, N.M. (2010). Rehionalna systema okhorony zdorovia: kontseptualni pidkhody do formuvannia yii suchasnoi polityky [Regional health system: conceptual approaches to the formation of its current policy]. Kyiv [in Ukrainian].

4. Dorofyeyev, V.M. (2008). Organizatsiya ambulatorno-poliklinicheskoy pomoshchi gorodskomu naseleniyu [Organization of outpatient care for the urban population]. Homel [in Russian].

5. (2010). Zakon Ukrainy № 1841- VI vid 22.01.2010 r. «Pro zatverdzhennia zahalnoderzhavnoi prohramy rozvytku pervynnoi medyko-sanitarnoi dopomohy na zasadakh simeinoi na period do 2011 roku [Law of Ukraine No. 1841-VI of January 22, 2010 «On approval of the national program of development of primary health care on the basis of family until the year 2011]. Vidomosti Verkhovnoi Rady Ukrainy № 13, stor. 380, stattia 126 [in Ukrainian].

6. (2012). Zakon Ukrainy № 3612-VI vid 07.07.2011 «Pro poriadok provedennia Reformuvannia systemy okhorony zdorovia u Vinnytskii, Dnipropetrovskii, Donetskii oblastiakh ta m. Kyievi» [Law of Ukraine No. 3612-VI of 07.07.2011 «On the procedure for reforming the health care system in Vinnytsia, Dnipropetrovsk, Donetsk oblast and Kyiv. Vidomosti Verkhovnoi Rady Ukrainy, № 12-13 [in Ukrainian].

7. Osnovni pokaznyky zdorovia ta medychnoi dopomohy naselenniu m. Kyieva u 2015-2016 rr. [Basic indicators of health and medical care for the population of Kyiv in 2015-2016]. Kyiv [in Ukrainian].

8. Nakaz Ministerstva okhorony zdorovia Ukrainy vid 30 hrudnia 2011 roku № 1008 «Pro zatverdzhennia prymirnykh polozhen pro zaklady okhorony zdorovia» [Order of the Ministry of Health of Ukraine dated December 30, 2011, No. 1008 «On Approval of Model Provisions on Health Care Institutions»]. Retrieved from: http: //search.ligazakon.ua/l_doc2.nsf/ link1/MOZ15003. html [in Ukrainian].

\section{ХАРАКТЕРИСТИКА ДЕЯТЕЛЬНОСТИ АМБУЛАТОРНЫХ УЧРЕЖДЕНИЙ ГОРОДА КИЕВА В УСЛОВИ- ЯХ РЕФОРМИРОВАНИЯ СИСТЕМЫ ЗДРАВООХРАНЕНИЯ}

В.В. Кравченко

Национальная медицинская академия последипломного образования имени П.Л. Шупика, г. Киев, Украина

Создание новых структур в системе здравоохранения требует комплексного и тщательного анализа их деятельности с целью обоснования возможностей усовершенствования ее организации. 
Цель: провести анализ сети амбулаторно-поликлинических учреждений, ресурсов и деятельности консультативно-диагностических центров в г. Киеве в 2014-2016 гг.

Материалы и методы. Материалами для проведения анализа выступили данные отчетных статистических фрорм № 17, № 20, а также статистические справочники Киевского городского информационноаналитического центра.

Результаты. В г. Киеве на базе существующих поликлиник создано 28 центров первичной медикосанитарной помощи и 13 консультативно-диагностических центров. Консультативно-диагностические центры обеспечивают 38,6-57,1 \% всех посещений в амбулаторно-поликлинических центрах. Основными ресурсными проблемами консультативно-диагностических центров является недостаточное сринансирование, устаревшее лечебно-диагностическое оборудование, неполная укомплектованность кадров.

Выводы. Выявленные характерные особенности деятельности консультативно-диагностических центров будут учитываться при разработке фрункционально-организационной модели консультативнодиагностических центров на принципах дпП.

КЛЮЧЕВЫЕ СЛОВА: амбулаторно-поликлинические учреждения в г. Киеве; ресурсы; показатели деятельности.

\section{CHARACTERISTIC OF THE AMBULATORY MEDICAL CARE IN KYIV IN THE CONDITIONS OF HEALTH CARE SYSTEM REFORMING \\ V.V. Kravchenko \\ P. Shupyk National Medical Academy of Postgraduate Education}

The creation of new structures in the healthcare system requires a comprehensive and thorough analysis of their activities with a view substantiate the possibilities for improving theirs organization.

Purpose: analyzing the network of outpatient clinics (APC), the resources and activities of the Consultative and Diagnostic Centers (CDC) in Kyiv in 2014-2016.

Materials and Methods. The data from statistical forms No. 17 No. 20, as well as statistical directories of the Kyiv City Information and Analytical Center, were used for the analysis.

Results. In Kyiv on the basis of existing polyclinics 28 primary health care centers and 13 CDC were established. CDCs provide $38.6 \%-57.1 \%$ of all visits to the APC, which indicates a significant contribution of these institutions to outpatient care to the adult population of the capital. The main problems of resources in CDC are insufficient funding, obsolete medical diagnostic equipment, incomplete staffing.

Conclusions. The results of the study will be used to substantiate the conceptual directions of improving secondary outpatient care for the population of Kyiv and to develop a model of CDC on the principles of publicprivate partnership.

KEY WORDS: out-patient clinics in Kyiv; resources; indicators of activity.

Рукопис надійшов до редакції 23.10.2017 p.

Відомості про автора:

Кравченко Василь Віталійович - заслужений лікар України, кандидат медичних наук, докторант кафредри управління охороною здоров'я НМАПО імені П.Л. Шупика. 